\title{
Henry Frost: Pioneer Music Education in Upper Canada
}

\author{
BY JAMES MASON \\ UNIVERSITY OF TORONTO
}

Music education in Upper Canada during the first half of the nineteenth century was diverse and quite varied. There were a number of factors that influenced the quality of education, and whether or not music was included at all. Various legislation, along with immigration from Europe, the United Kingdom and the United States (and the educational philosophies immigrants held), were important factors. At the turn of the nineteenth century no state-supported school system existed in Upper Canada, though the situation was in flux. Curricula varied from community to community, as did the quality of instruction.

This was the varied and fragmented education system that Henry Frost taught in. The manual that Frost left for us is a valuable resource for understanding and conceptualizing how music education was, in at least this one example, taught in Upper Canada. It demonstrates the common educational and music instructional philosophies of the time, seen in the Old World and in the United States.

Henry Frost taught between 1835 and 1850 at York County, King's township, 3rd concession, where he died in 1851. Frost would have taught in what was known as a common school (which later became what is now known as a public school). ${ }^{1}$ However, according to established education patterns in Upper Canada, he probably used the manual in "singing school" sessions for adults as well. It is also likely that Frost had something to do with the worship music in St. Andrew's Church at Eversley; ${ }^{2}$ no records exist, however, due to a fire destroying the church and its archives. Haig says, "The typical Presbyterian Church of that period had no organ, no choir, and the preceptor with the aid of a tuning fork ... thundered out the psalm tunes at Sabbath services. It was a tradition in Scotland as well as in the Presbyterian churches in Canada for the preceptor to be the local schoolmaster." ${ }^{3}$ Henry Frost introduced music to supplement the curriculum. Having no resources or equipment, Frost produced a twelve-volume manual constituting a complete course in the rudiments of music. The manual consists of 192 pages in total. Each page, roughly $51 \mathrm{~cm}$ by $36 \mathrm{~cm}$, is handwritten and easily

\footnotetext{
${ }^{1}$ Alastair P. Haig, "Henry Frost, Pioneer," The Canadian Music Journal (Winter 1958), 35.

${ }^{2}$ Ibid., 35.

${ }^{3}$ lbid., 38.
} 
read by students up to six or seven metres away, so that it could be seen at the back of a classroom. ${ }^{4}$

\section{HISTORY OF THE MANUAL}

After having created and used his manual, Henry Frost passed it on to the local blacksmith, Thomas Scott. Scott had forged tuning forks for Frost, and replaced Frost as the local school teacher after Frost's death. Scott left the manual with his descendants, who, in turn, passed it on to Principal James T. Jenkins of the Jarvis Institute in Toronto. The manual became part of a textbook collection held by the Ontario College of Education. ${ }^{5}$ In 1972, the Ontario College of Education became the Faculty of Education in the University of Toronto. ${ }^{6}$ In 1992 the Faculty of Education merged with the Ontario Institute for Studies in Education (OISE). Perhaps Frost's manual became part of the OISE collection after amalgamation, but its whereabouts is unknown.

During the 1950s while completing his doctoral work in music education in Upper Canada, Cam Trowsdale had the manual microfilmed. Years later, after learning of tape degradation and mindful of the lack of original source material in this area of study, Trowsdale had the microfilm digitally transferred, and donated a copy to the University of Toronto Faculty of Music Library, as well as to OISE. ${ }^{7}$

The manual created by Henry Frost is rare: Cam Trowsdale says, "so little primary source material ... exists regarding early music teaching in the province." ${ }^{8}$ And in later correspondence, he states: "it is the only document of its kind that has survived intact (at least with which I'm familiar) which provides an indication of what was taught in a Canadian singing school prior to the establishment of publicly funded education." ${ }^{9}$

\section{FRAGMENTED EDUCATION SYSTEM}

The education system during the first part of the nineteenth century was at a very early stage of development in Upper Canada. There were different types of schools intended for different types of students. What was definitely lacking was a uniform approach to education and curriculum. Most prominently established, or establishing themselves,

\footnotetext{
${ }^{4}$ Ibid., 35.

"Fast Facts," University of Western Ontario, accessed July 18, 2011, http://www.edu.uwo.ca/about-us/fast-facts.html. ${ }^{6}$ Ontario Institute for Studies in Education, [ca. 2011], in Facebook [Group page], accessed July 18, 2011.

${ }^{7}$ George Campbell Trowsdale, Vancouver, B.C., email to Kathleen McMorrow, Toronto, ON, 26 January 2011.

${ }^{8}$ George Campbell Trowsdale, "A History of Public School Music in Ontario," Ed.D., dissertation, University of Toronto (Canada), 1962 (AAT NK21416): 50.

${ }^{9}$ Trowsdale, email.
} 
were private schools and grammar schools. For the less fortunate of Upper Canada, the education system was a ramshackle collection of facilities known as common schools. For Frost, as previously mentioned, singing schools would also have been relevant to his educational activities. There were also academies, monitorial schools, and normal schools.

Private schools were fairly well established by 1800 , and could be found in Newark, York, Ancaster, Cornwall, Kingston, Adolphustown, St. Catharines, and Belleville. ${ }^{10}$ They were supported by fees. Frequently the teachers were clergymen, with the principal subjects being reading, writing, and arithmetic. ${ }^{11}$ The private schools were not governed by legislation defining their structure and curriculum. Furthermore, they lacked funding and support from the state.

In 1807 the Legislature passed the District School Act (DSA), ${ }^{12}$ which resulted from a House of Assembly and Legislative Council proposal in 1797 to allocate Crown land for the establishment of a grammar school in each District. ${ }^{13}$ Grammar schools were the earliest state-funded schools to emerge. John Graves Simcoe (first LieutenantGovernor of Upper Canada) worked to establish these. Simcoe feared that the younger generation was "rapidly returning to barbarism." ${ }^{14}$ Further, he feared Britain's failure to fund these institutions in Upper Canada would inevitably result in respectable settlers being lured to the United States for the education of their young.

These grammar schools were still intended for the "ruling classes," and levied considerable fees. The curriculum was largely classical, and still lacked any uniformity. ${ }^{15}$

The advent of the grammar schools was progress, yet it did little for the children of the settlers. In an attempt to remedy that situation, Sir Francis Gore, Lieutenant Governor, addressed the Legislature, suggesting what was needed was a system of township schools accessible to children of the settlers. ${ }^{16}$ This led to the passing of the Common Schools Act of 1816. This was a great step forward for what would become the "public school." The law provided for the sum of $\$ 24,000$ a year for four years to establish

\footnotetext{
${ }^{10}$ Ontario, Dept. of Education, “Documentary history...," (Warwick \& Rutter Printers, 1894-1910), 31.

${ }^{11}$ John Harold Putnam, Egerton Ryerson and Education in Upper Canada (Toronto: W. Briggs, 1912), accessed July 18, 2011, http://www.qutenberg.ca/ebooks/putman-egertonryerson/putman-egertonryerson-00-t.txt.

${ }^{12}$ J.M. Mangan and A. Davidson-Harden, "Ontario Schools in Social and Cultural Context," in Social Foundations of Education Coursebook 2004-2005 (London, Ontario: The University of Western Ontario, 2007).

${ }^{13}$ W. R. Wilson, "Education in Upper Canada: History is a Race Between Education and Catastrophe," accessed July 18, 2011, http://www.uppercanadahistory.ca/lteuc/lteuc6.html.

${ }^{14}$ Ibid.

${ }^{15}$ Putnam.

${ }^{16}$ Ibid.
} 
common schools, under the public control, for the "common people." The legislation allowed that "the people of any village, town or township might meet together and arrange to establish one or more schools, at each of which the attendance must be not less than twenty." ${ }^{17}$ Three suitable trustees were to be chosen to manage the school, appoint teachers, and select textbooks from a list prescribed by the District Board of Education. The establishment, structure and organization were largely left up to the communities establishing the institutions. Understandably, there existed much divergence in practice and curricula. ${ }^{18}$

In 1846, the Common School Act was revisited with the aim of providing more structure and uniformity. This is now thought of as the "first organized school system," ${ }^{19}$ in Upper Canada. It was based largely on the Irish system of the time, and was established following many of the recommendations stipulated in a report on public education provided to the legislature by Egerton Ryerson, Chief Superintendent of Education for Upper Canada in $1844 .{ }^{20}$ This report, titled "Report on a System of Public Instruction for Upper Canada," included a chapter on vocal music.

Before legislated curricula, music was taught in common schools as early as 1837 . For example, the teacher of an Indian school at Alderville in 1837 taught music to his class and, when visiting various American cities on behalf of the Indian Missions, "took with him some of the children of the School, whose singing always delighted the people." 21

It was the common school in which Henry Frost taught. As previously mentioned, prior to 1846 the curriculum was not uniform, and would have been largely established by Frost himself. Notably, his approach to music education quite closely foreshadowed what was to be suggested as the model for music education in the new common schools after 1846 .

Along with grammar schools and common schools, there also existed academies such as Upper Canada College. These "academies" were situated somewhere between grammar and commons schools - partially funded by the government, and arising out of the need for quality education for a burgeoning wealthier class. "Monitorial" was another system of schooling in which schools housed hundreds of pupils under a single

\footnotetext{
${ }^{17}$ Wilson.

${ }^{18}$ Putnam.

${ }^{19}$ George Campbell Trowsdale, "Vocal Music in the Common Schools of Upper Canada: 1846-1876," Journal of Research in Music Education 18, no. 4 (January 1970), 340.

${ }^{20}$ Putnam.

${ }^{21}$ Trowsdale, "Vocal Music," 341.
} 
master, with senior pupils used as teaching monitors; though popular in Europe, they were never very prominent in Upper Canada. Most relevant to Frost, other than common schools, would have been the singing schools. These schools were an indigenous American institution, which made their way to Upper Canada as well. Dr. J. A. Caroll, (who lived 16 miles from the town of York), referred to one, saying, "A so-called Sunday-school and a ... singing school which followed on its heels."

\section{INFLUENCES ON EDUCATION}

Soaring population growth in Upper Canada during the early part of the nineteenth century would have had a significant impact on the need for quality education, and the implementation of that education. During the early 1800 s the population of Canada grew from around 70,000 to more than $400,000 .{ }^{23}$ Many of these immigrants came from England, Germany, and the United States.

As previously stated, immigrants from the United States brought singing schools. Further, music was regularly taught in the United States at this time, and immigrants would have expected it, and helped implement it: "Music is now regularly taught in a large proportion of their schools in the New York and New England States." ${ }^{24}$ One such immigrant from the US was Mr. S. M. Haskins, who is remembered as "a most excellent and painstaking teacher hailing from Rochester, N.Y." ${ }^{25}$ Mr Haskins was, "the first teacher ... that held quarterly Public Examinations in which were introduced Singing, Dialogues, Recitations, Debates etc." These examinations were established in the 1800s.

Other major influences from the United States would have been music education philosophies championed by Lowell Mason, Principal of the Boston Academy of Music. The Boston Academy educated many of the burgeoning American musical culture, and ultimately educators who brought music into the classroom. While at the Academy, Mason published his The Manual of the Boston Academy of Music, which was an edited translation of G.F. Kuebler's Anleitung zum Gesang-Unterrichte in Schulen, which Lowell Mason suggested was based on Pestalozzian principles. This manual was used for many years by music teachers in the US. ${ }^{26}$

\footnotetext{
${ }^{22}$ Trowsdale. "Vocal Music," 343.

23“"Estimated Population of Canada, 1605 to Present," Statistics Canada, accessed July 18, 2011.

${ }^{24}$ Ontario, Dept. of Education, 129.

${ }^{25}$ Trowsdale, "Vocal Music," 342.

${ }^{26}$ Harry Eskew, et al, "Mason," in Grove Music Online, Oxford Music, accessed July 18, 2011, http://www.oxfordmusiconline.com/subscriber/article/grove/music/17984pg1.
} 
Immigration from the Old World also brought many influences on music education. Vocal music, for example, constituted a portion of elementary education throughout the United Kingdom. ${ }^{27}$ As with American immigrants and the influence of the Boston Academy, many music teachers in Upper Canada would have been graduates of institutions such as the famous "Glasgow Training College." In this College, under Principal David Stow, music played a prominent role. This suggests graduates may, in turn, have also taught music. ${ }^{28}$ It is not clear how direct these influences were on Frost, but his manual does demonstrate an understanding of the trends in music education in the United Kingdom.

European immigration was likely also an influence. Music had been taught in German schools for decades, and was becoming increasingly common in public schools across Europe..$^{29}$ The teaching philosophy of Johann Heinrich Pestalozzi was becoming very influential in European communities as well. Concepts such as rote learning, "things before signs," and singing songs took a prominent place in his "moral" education. Pestalozzi stated, "the effect of music in education is not only to keep alive a national feeling: it goes much deeper; if cultivated in the right spirit, it strikes at the root of every emotion unworthy of humanity." 30

The approach championed by Pestalozzi is realized in music education in methods devised by later educators such as Pfeiffer and Nageli in their Gesangbildungslehre, Orff, and Koday. With music we see a focus on active and sensory learning; teaching sounds before signs; separating music into component parts such as melody, rhythm, and expression; and progressing from the simple to complex within the context of each element. These concepts were clearly demonstrated in the manual of Frost.

\section{The Manual of Henry Frost}

As previously mentioned, Ryerson's report was quite influential in developing the curriculum for the common schools, which included music. In the report, Ryerson states that vocal music is, "another department of instruction which I think, ought to find a place in every common school." ${ }^{31}$ As a basis for the music aspect of curriculum in Upper Canada, Ryerson used a method devised by John Hullah, who based his manual on one written by Wilhelm which was used in France. Hullah's manual was to be used as a

\footnotetext{
${ }^{27}$ Egerton Ryerson, "Report on a System of Public Elementary Instruction for Upper Canada," (Montreal: [s.n.]), 151.

${ }^{28}$ Trowsdale, "Vocal Music," 342.

${ }^{29}$ Ryerson, 125.

${ }^{30}$ Wilfried Gruhn, "Is Lowell Mason's "Manual" Based on Pestalozzian Principles? An Inquiry into the Controversy of Methods in the Nineteenth Century," The Bulletin of Historical Research in Music Education 14, no. 2 (July, 1993), 94.

${ }^{31}$ Ryerson, 125.
} 
model for music instruction in the curriculum for the schools in the United Kingdom. On review of Hullah's method, published in 1846, the similarities between it and the manual of Frost are evident, suggesting that Frost was quite aware of current trends in music education.

Frost's manual predates Hullah's method, which was used as the model for the curriculum in Upper Canada after the 1846 School Act passed. What is evident is that they both followed Pestalozzi thoughts, separating music into melody, rhythm, and expression, moving from the simple to complex within the context of each element. In Hullah's method we see instruction on how to teach concepts, whereas in Frost's manual we just see examples; the curriculum is not stated explicitly. Though both Frost and Hullah roughly follow the same divisions in musical concepts, they approach them differently. Frost starts with time (fig. 1a), whereas Hullah starts with melody (fig. 1b).

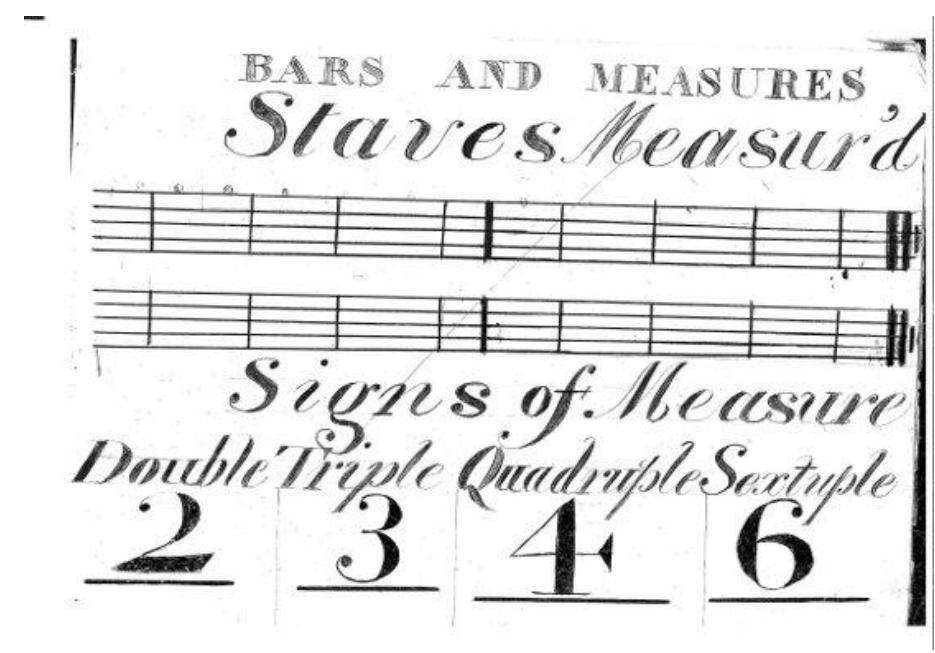

Fig. 1a 


\section{FIRST COURSE. \\ PART I. \\ Cuapter I. SCALES AND INTERVALS. \\ Prepare Sheet No. 1.}

1. Sounns which are so confused and harsh that the ear cannot follow them, nor the voice imitate them, are noise. Sounds which the ear can follow, or the voice can imitate, are music. The rolling of cart-wheels, or the blows of a hammer, we should call noise; whereas the ringing of church-bells, or even the singing of birds, we should call music.

a. That is noise.

The Teacher will strike the wall with his wand or stamp on the floor.

b. That is muszc.

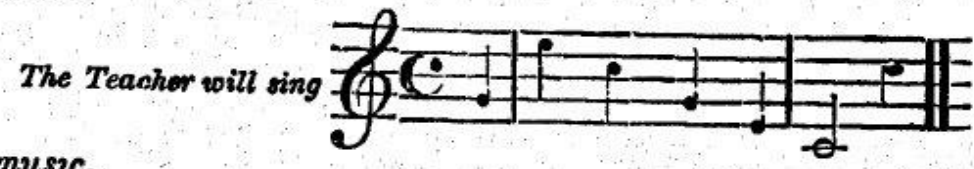

2. Music that we can produce with our own voices is called vocal musie; music which has to be produced by instruments-organs, violins, or flutes-is called instrumental music.

c. We are going to study rocal music.

3. Words whic.l being placed in a particular order have a meaning form what is called a "passage" or sentence. Sounds, also, when they follow one another so that, on being sung or played on an instrument, they can be followed by the ear and known from other sounds, form a " musical passage."

d. The sounds I sang just now formed a musical passage; what I am about to sing will form another.

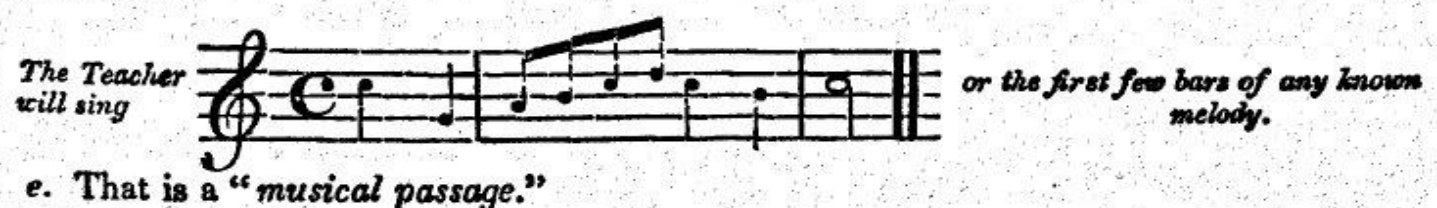

4. Every musical passage is said to be in some particular scale.

5. A scale is a succession of eight or more different sounds which, beginning on any one sound, proceeds to what is called the octave of that sound.

Fig. $1 b^{32}$

32John Hullah, Wilhem's Method of Teaching Singing (1842), (Kilkenny: Reproduced under the direction of Leslie Hewitt for Boethius). NB: All images from the Hullah manual come from this edition. 
In figure 1a we see an image from the beginning of Frost's manual, juxtaposed with the beginning of Hullah's manual in figure 1b. Here one can see that Frost has no written explanation as to how these diagrams are to be used for instruction, whereas the Hullah method goes into a fair amount of detail. And furthermore, it shows that Frost and Hullah progress through the rudimentary material in a different fashion.

The Frost and Hullah methods share much in terms of details. In figure 2, we see a "ladder" diagram which is very similar in the Hullah (left image), and the Frost (right image), manuals. Hullah denotes sol-fa, and degree names. Frost states the sol-fa, degree and functional names of the notes (do; tonic; 1 ). Neither, at this point, stipulate pitch.
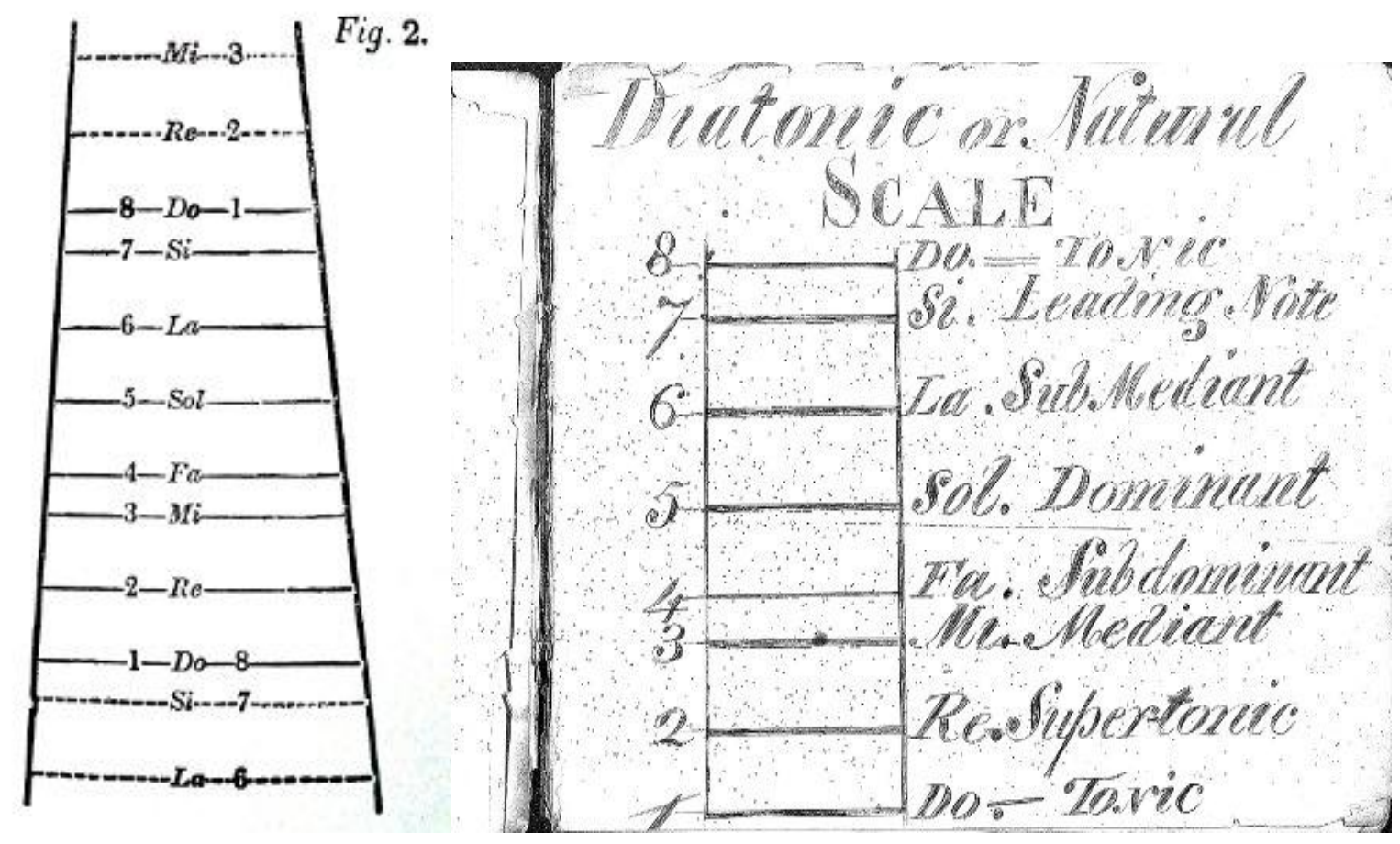

Fig. 2 
Though they do share many similarities, there are some notable differences in approach as well. Here, in figure 3, we see an interesting diagram with a "hand" (reminiscent of Guido's), illustrating notes on the staff. This diagram was used many times in Hullah's method, but never in Frost's. It also demonstrates the use of the "fixed doh" system.

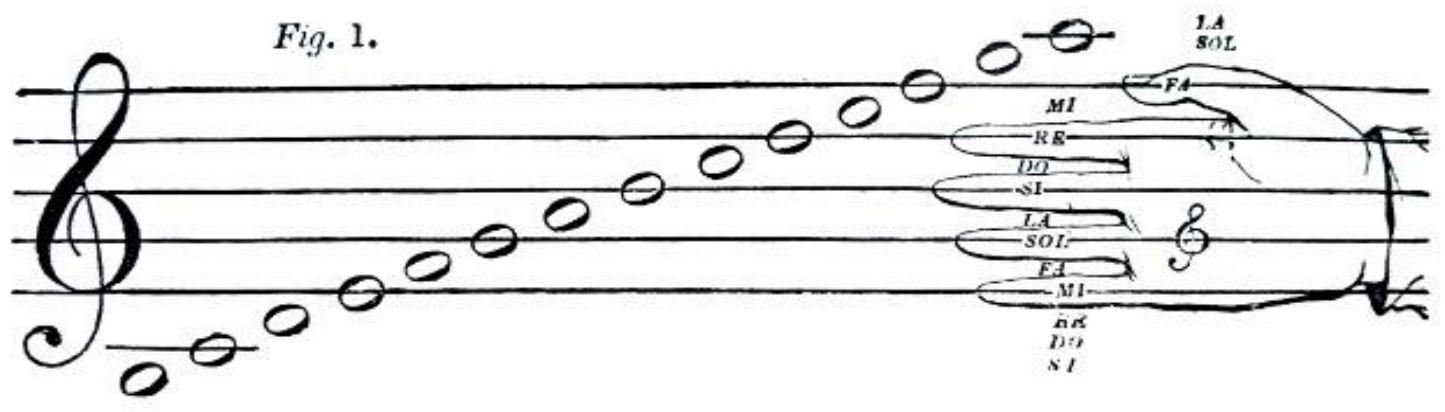

Fig. 3

In the teaching of time both use similar diagrams, yet Hullah uses the British nomenclature (breve, semibreve, minim, etc.), whereas Frost favours the system commonly used in Canada (whole note, half note, quarter, etc.).

Very similar charts showing beating patterns are used throughout the Hullah and Frost manuals, as seen in figure 4 (Hullah's example on the right, Frost's on the left).
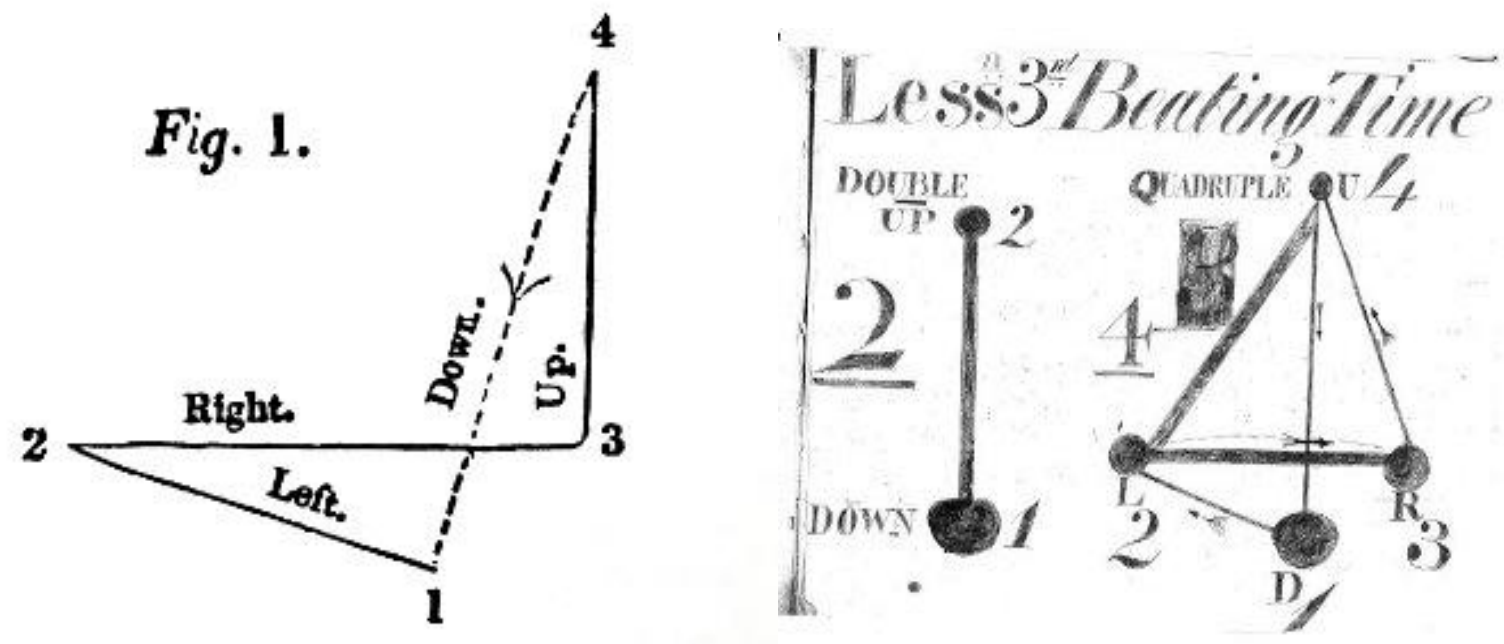

Fig. 4 
Where Frost uses many charts to demonstrate rhythmic values and their relationships throughout his manual, Hullah uses just one very comprehensive chart (see fig. 5).

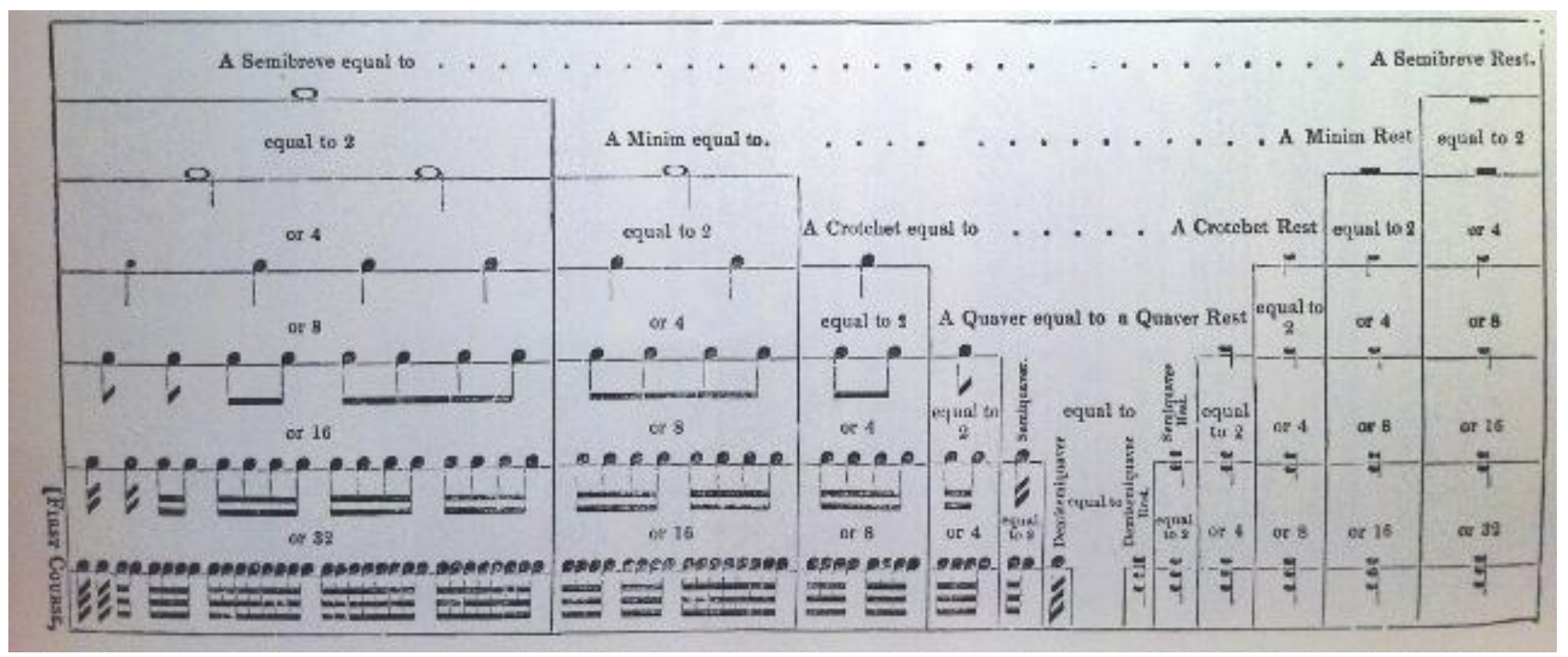

Fig. 5

Frost provides many examples of comparative rhythmic charts. Figure 6 shows two examples.

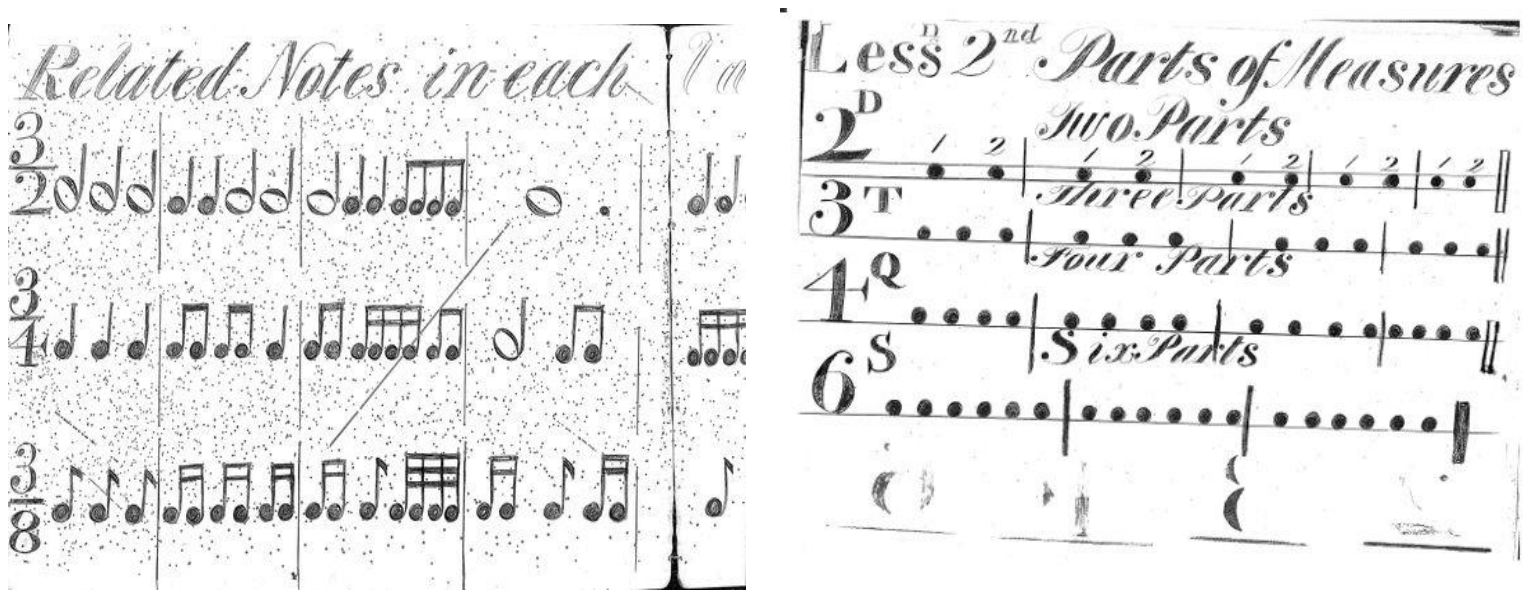

Fig. 6 
Comparing the manuals of Frost and Hullah demonstrates that Frost was very aware of music education principles, and was able to express them in a personal fashion, modifying them to suit his own individual ideas.

As mentioned earlier, Frost starts his manual with the teaching of time, then moves to melody, and finishes with expression.

\section{THE TEACHING OF TIME}

Frost starts as basic as can be with a diagram of the staff (see fig. 1a). From there, Frost progresses through different types of measures - double, triple, quadruple, sextuple - and how to count the measures (see fig. 7).
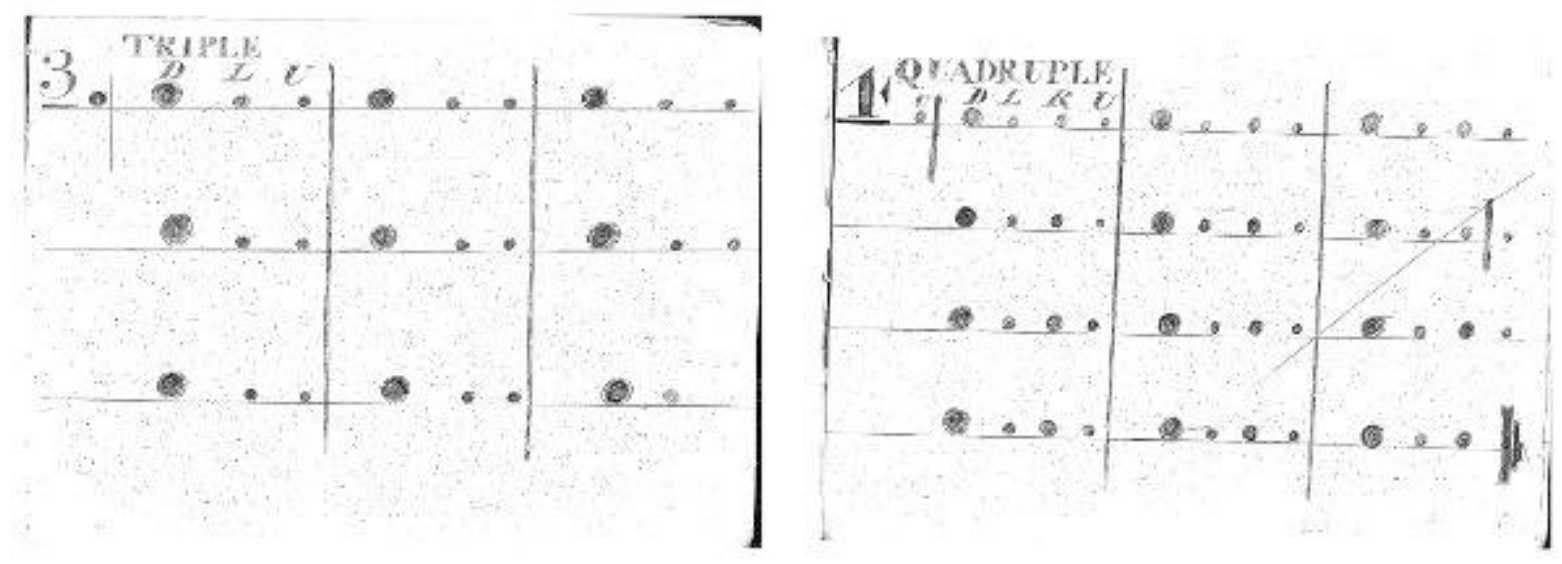

Fig. 7

In figure 7 we see counting patterns for different types of measures, and in figure 8 , as with the examples in figure 7 , we see strong beats notated with symbols used in his beating charts (see fig. 4), D,L,R,U, (presumably for Down, Left, Right, and Up). Also, one can see that the accompanying text, "let us all correct-ly sing...," is notated without pitch, simply rhythm at this point, effectively demonstrating a type of rhythmic speech (predating elements of Orff's technique). ${ }^{33}$

${ }^{33}$ Trowsdale, "'History of Public School Music." 


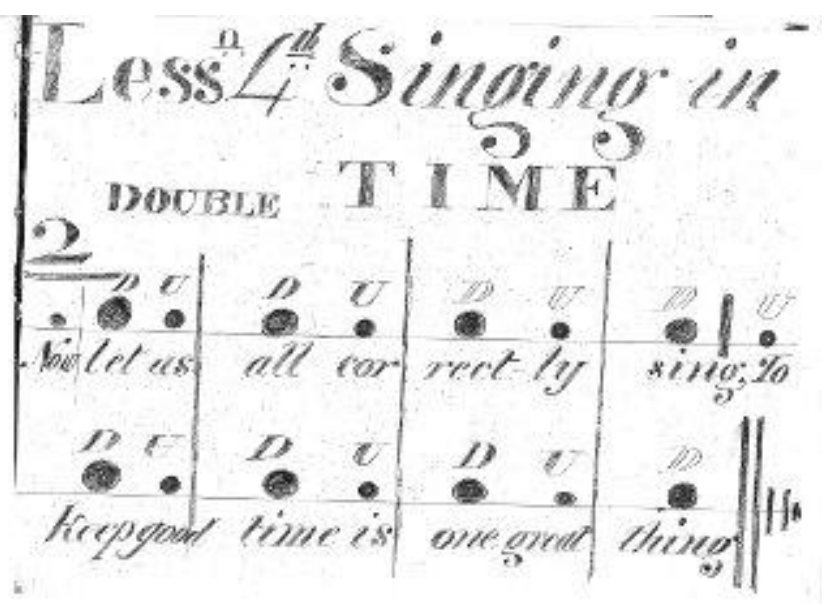

Fig. 8

Grades of time, as seen in figure 9, are demonstrated as well.

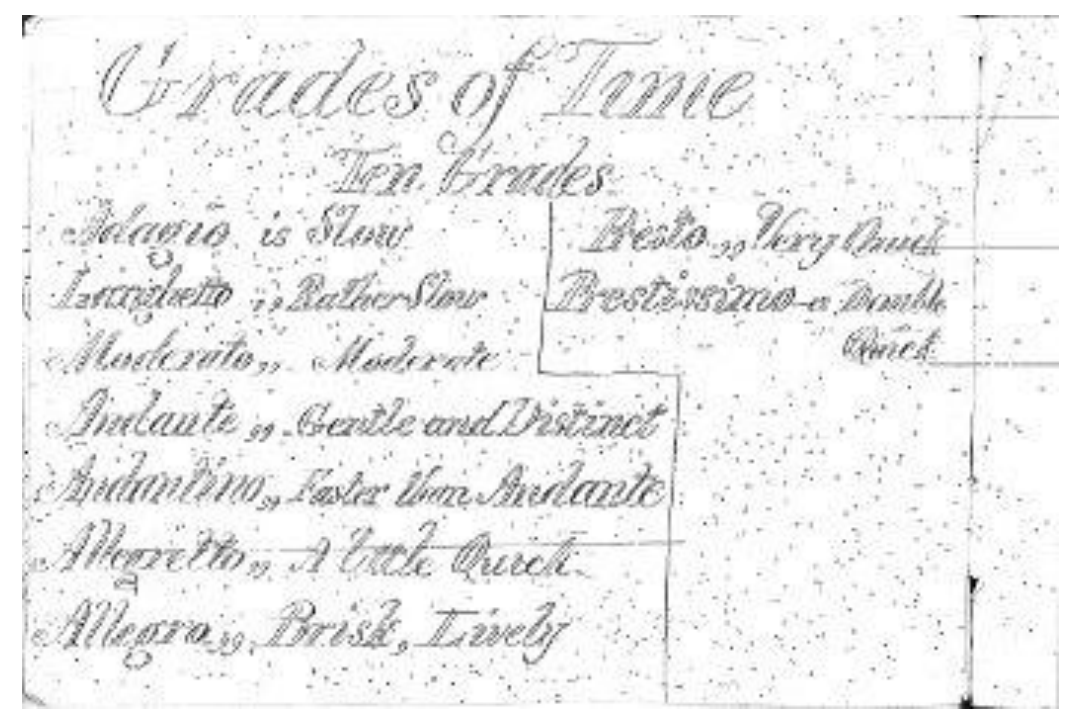

Fig. 9

Frost incorporates many exercises to practice the varieties of measure, rhythms and values explored in the first section. 
Frost utilizes the use of different nomenclature for notes of the scale, including letter names, (e.g., a, b, c), sol-fa (movable), degree, (e.g., 1, 2, 3-8), and function, (e.g., leading note, mediant). Also, as mentioned earlier, he introduced the ladder concept. See figure 10.

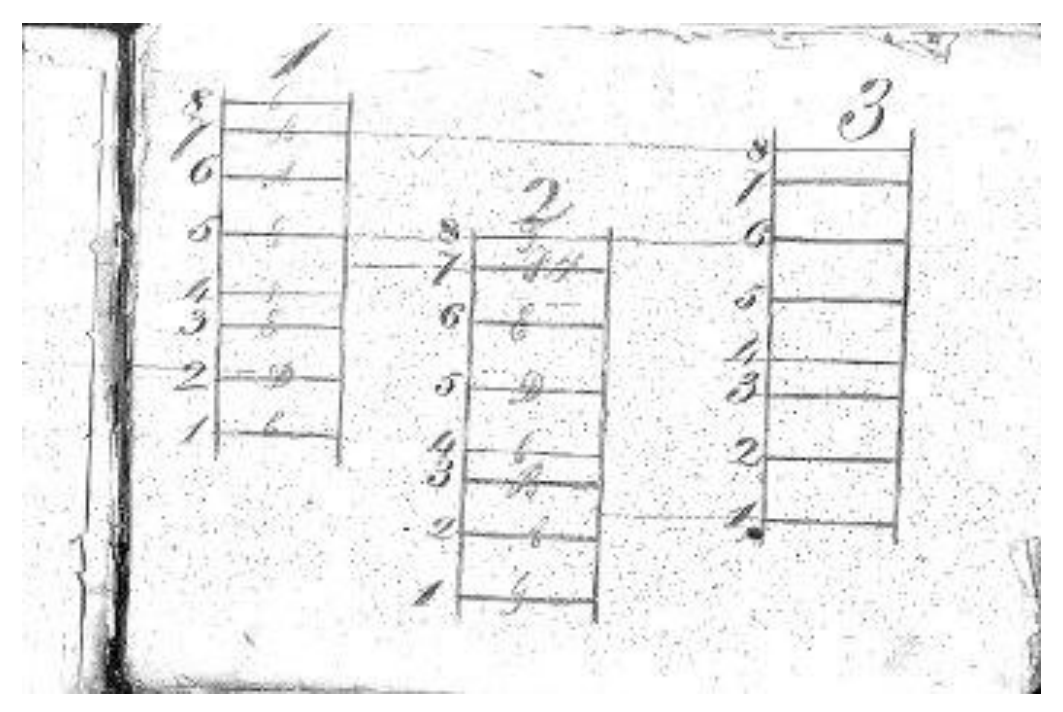

Fig. 10

In the ladders, in figure 10, one can notice a mistake. In the third ladder, representing the key of $B$ b major, notes are not labeled, and the line to connect the tonic of the third chart to the lowered 7 th of the first chart, actually corresponds to the 7th degree (he connects what is to be a B b in the third "ladder" with the B in the first "ladder"). Another thing to note in figure 10 is the use of more than one key: Hullah stayed with $C$ major for the whole first part of his manual, whereas Frost introduced different keys and scales. The natural minor, for example, is seen early on (see fig. 11). 

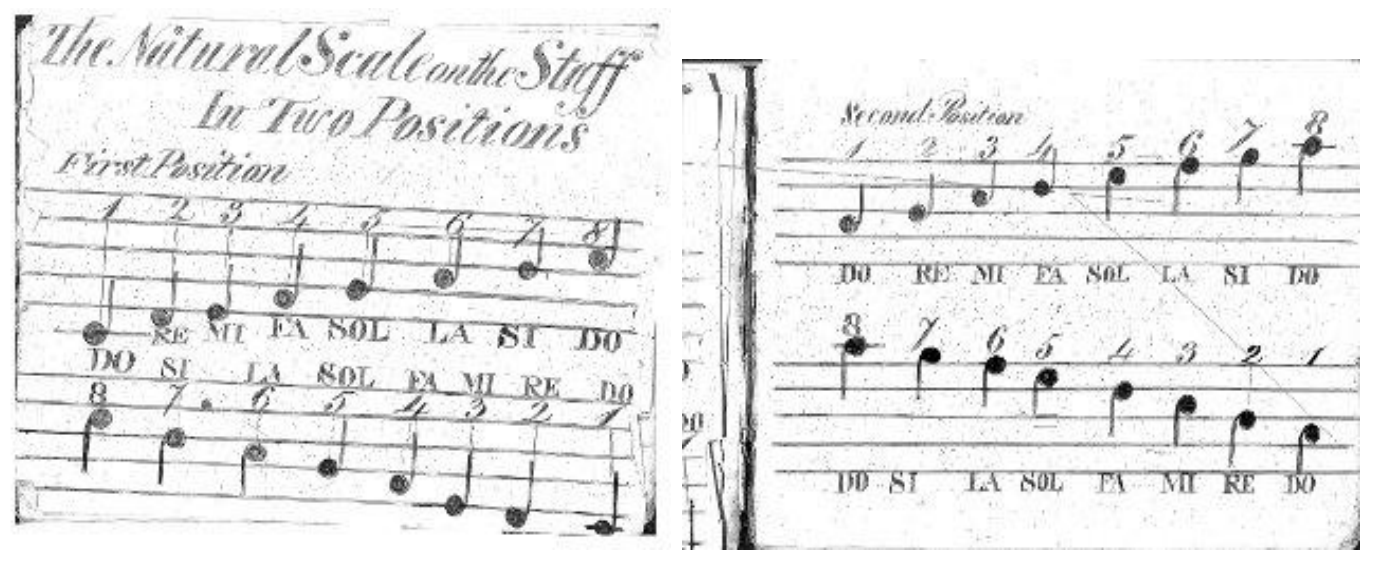

Fig. 11

In figure 11, Frost refers to the major scale and natural minor as first and second position respectively.

The manual also has many examples and exercises in various keys. These examples demonstrate the key signatures, sharps and flats, as well as accidentals. Also, in Frost's manual, there is the use of a movable doh, whereas Hullah used a fixed doh system (see fig. 12).
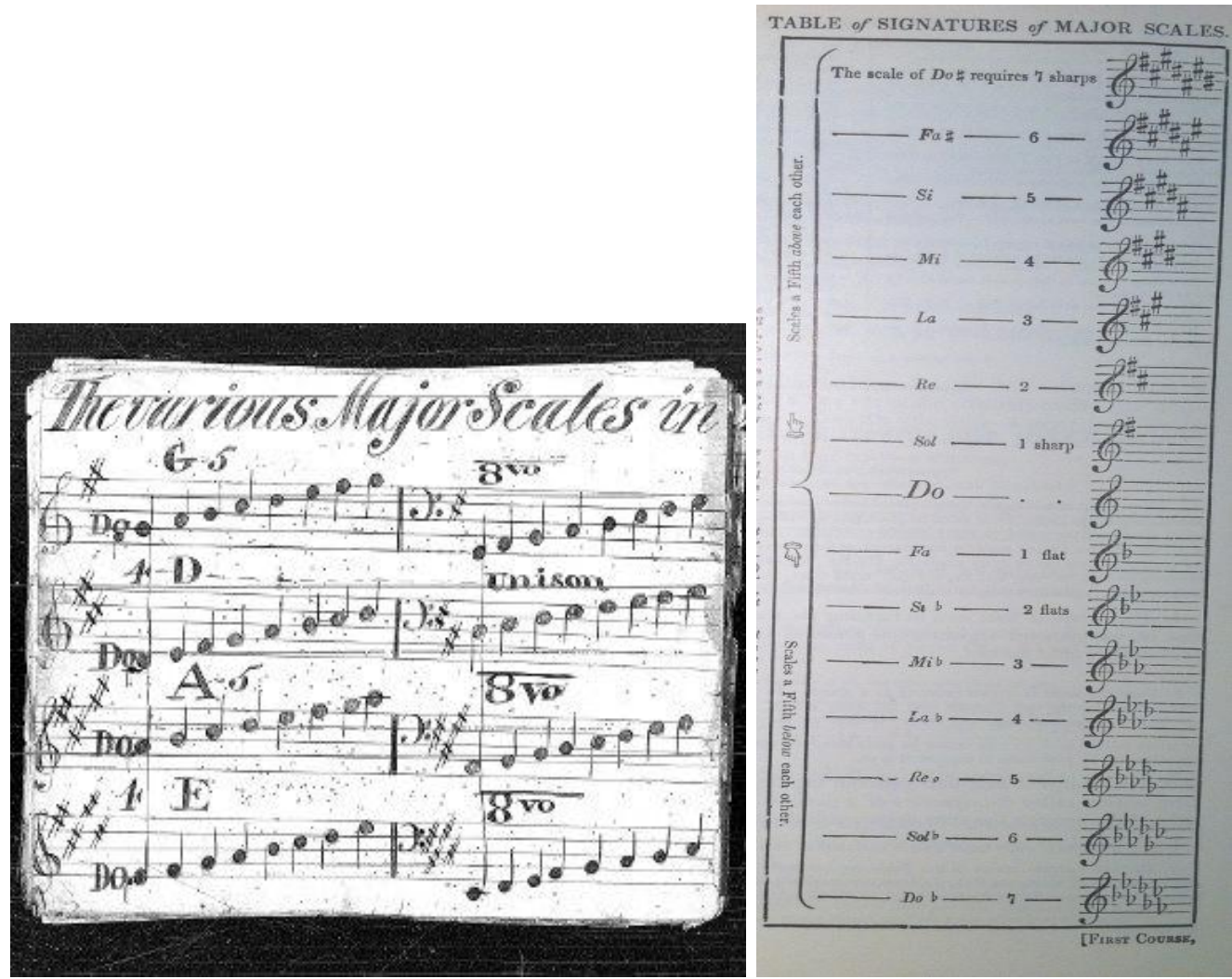

Fig. 12 
Frost introduces chords, songs, and rounds also (mainly in stepwise motion at first), intervals, and dissonances in the section on melody.

Voice types (fig. 13), and intervals (fig. 14), four part harmony, the extended scale and plenty of exercises are also introduced.

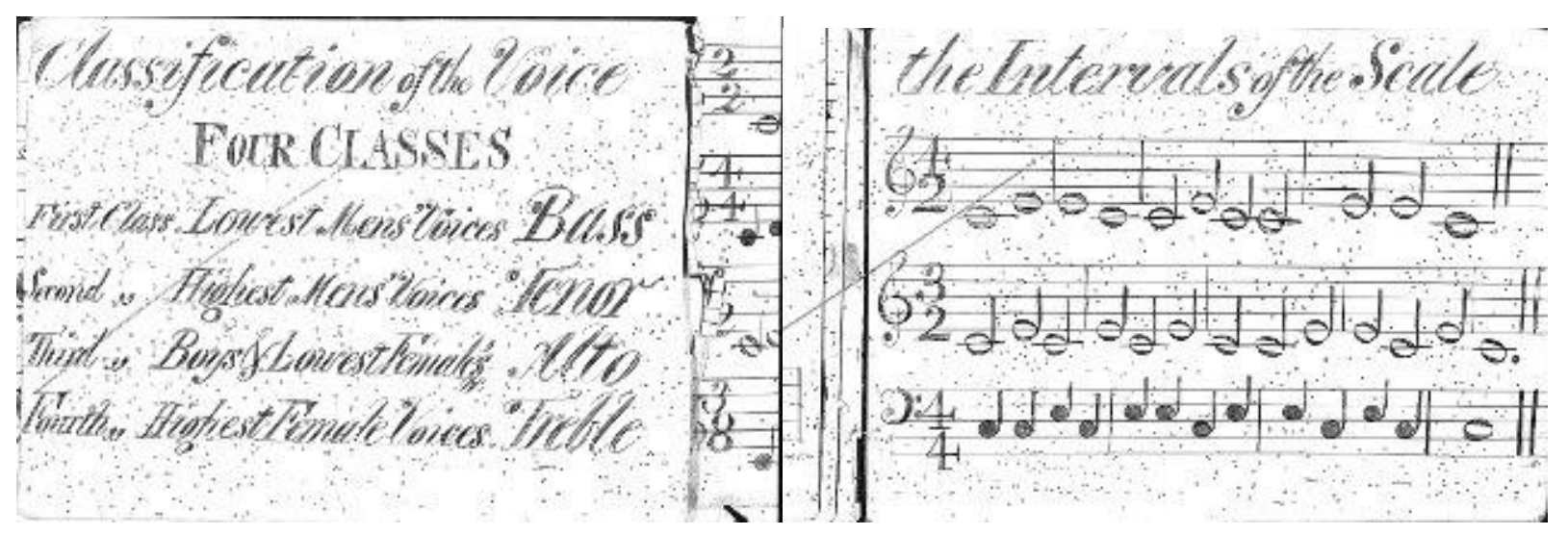

Figs. 13 and 14

THE TEACHING OF EXPRESSION

Dynamics and emphasis constitute a large part of the section on expression (see figs. 15 and 16).

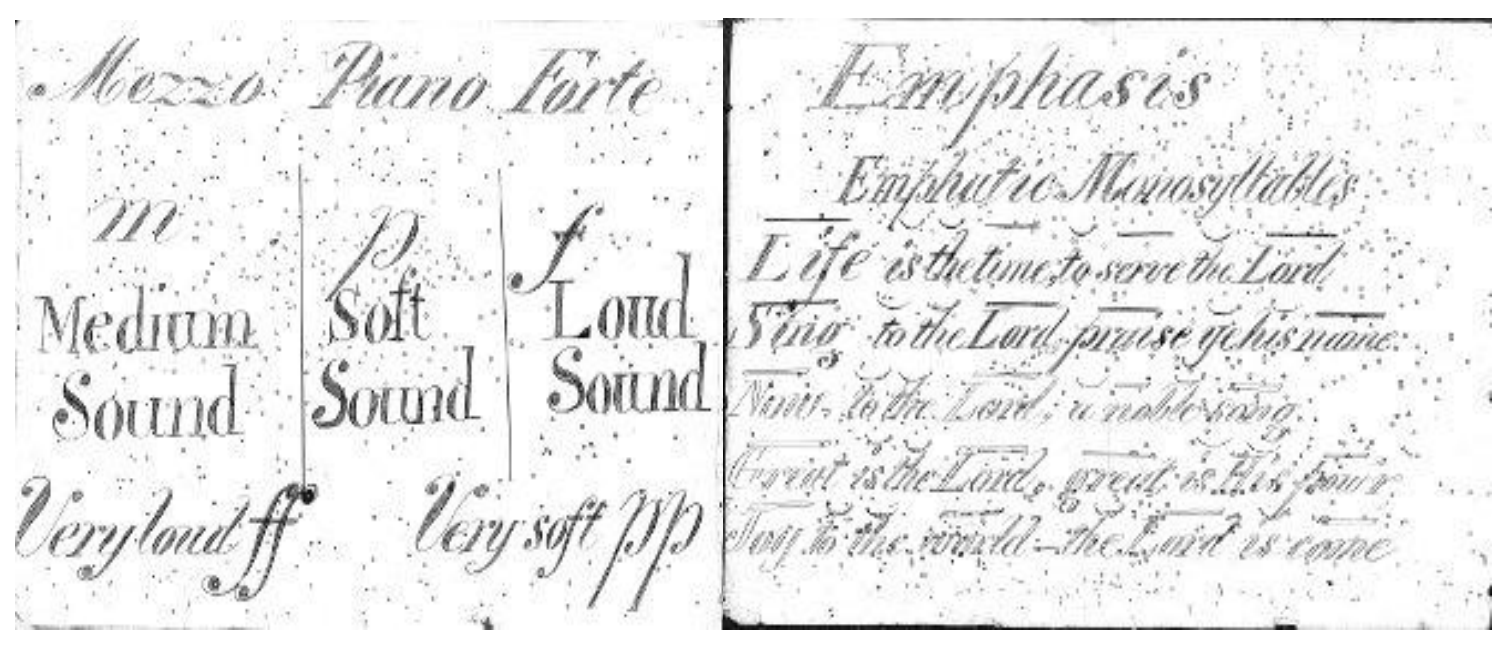

Fig. 15 
In figure 16 we see increase and decrease of sound illustrated.

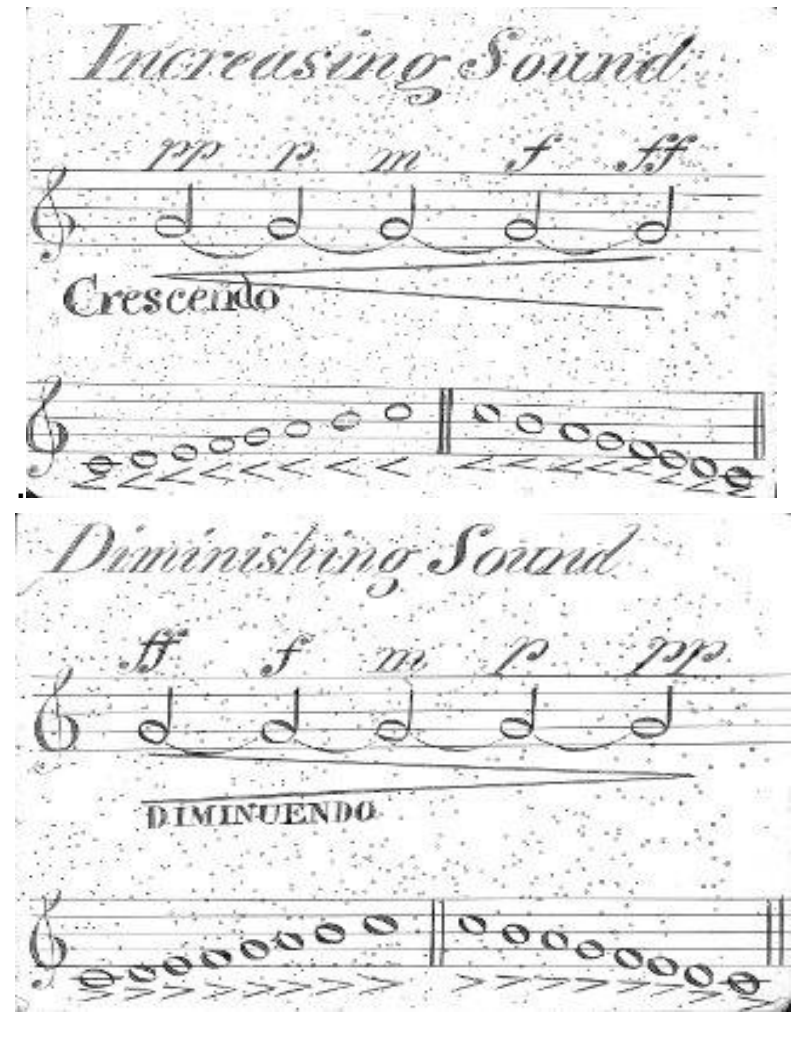

Fig. 16

Frost includes plenty of exercises showing aspects of expression, including explosive tones, articulation and emphasis, and practice with vocal and consonant sounds.

The manual of Henry Frost offers a rare primary source example of how music was taught in Upper Canada in the early part of the nineteenth century. The manual demonstrates an awareness of trends in education throughout the United States, Europe and the United Kingdom. For a closer look at Henry Frost's twelve-volume manual please visit the University of Toronto, Faculty of Music Library's Archival Collections: http://uoft.me/henryfrost. 


\section{WORKS CITED}

Eskew, Harry et al. "Mason." Grove Music Online. Oxford Music Online. July 18, 2011. http://www.oxfordmusiconline.com/subscriber/article/grove/music/17984pg1.

Gruhn, Wilfried. "Is Lowell Mason's 'Manual' Based on Pestalozzian Principles? An Inquiry into the Controversy of Methods in the Nineteenth Century." The Bulletin of Historical Research in Music Education 14, no. 2 (July 1993): 92-101.

Haig, Alastair P. "Henry Frost, Pioneer." The Canadian Music Journal (Winter 1958): 3540.

Hullah, John. Wilhem's Method of Teaching Singing (1842). Kilkenny: Reproduced under the direction of Leslie Hewitt for Boethius, 1983.

Houston, Susan, and Alison Prentice. Schooling and Scholars in Nineteenth-Century Ontario. Toronto: University of Toronto Press, 1988.

Mangan, J. Marshall, ed. "Social Class, Socio-economic Status, and Education." In Social Foundations of Education Coursebook, 2007-2008. London, Ontario: Althouse Press, 2007.

Ontario. Dept. of Education, and J. George Hodgins. 1894. Documentary History of Education in Upper Canada, from the Passing of the Constitutional Act of 1791 to the Close of the Rev. Dr. Ryerson's Administration of the Education Department in 1876. Edited, under the direction of the Minister of Education, with explanatory notes by J.George Hodgins. Toronto Dept. of Education. Toronto: Warwick Bros. \& Rutter, printers, 1894.

Ontario Institute for Studies in Education. 2011. Facebook, Accessed July 18, 2011. http://www.facebook.com/pages/Ontario-Institute-for-Studies-inEducation/108144255880106.

Putnam, John Harold. Egerton Ryerson and Education in Upper Canada. Toronto: W. Briggs, 1912. Accessed July 18, 2011. http://www.gutenberg.ca/ebooks/putmanegertonryerson/putman-egertonryerson-00-t.txt.

Ryerson, Egerton. Report on a System of Public Elementary Instruction for Upper Canada. Montreal: [s.n.], 1847. 
Trowsdale, George Campbell. "A History of Public School Music in Ontario." Ed.D., University of Toronto (Canada), 1962. (AAT NK21416).

- . "Vocal Music in the Common Schools of Upper Canada: 1846-1876." Journal of Research in Music Education 18, no. 4 (January 1970): 340-354.

University of Western Ontario, Faculty of Education. "Fast Facts." Accessed July 18, 2011. http://www.edu.uwo.ca/about-us/fast-facts.html.

Wilson, W. R. "Education in Upper Canada: History is a Race Between Education and Catastrophe". Accessed July 18, 2011. http://www.uppercanadahistory.ca//teuc/lteuc6.html. 